\title{
Clinical and histological responses to laparoscopically-induced peritonitis in rats $^{1}$
}

\author{
Resposta clínica e histológica à indução de peritonite via laparoscopia em ratos
}

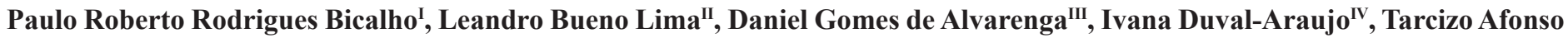 \\ Nunes $^{\text {IV }}$, Fabíola Alves dos Reis ${ }^{\mathrm{V}}$ \\ ${ }^{\text {I }}$ Fellow Master degree, School of Medicine, Federal University of Minas Gerais (UFMG), Belo Horizonte - MG, Brazil. \\ II Graduate student, School of Health Sciences, Vale do Rio Doce University, Governador Valadares - MG, Brazil. \\ III Assistant Professor, Division of Pathology, School of Health Sciences, Vale do Rio Doce University, Governador Valadares - MG, Brazil. \\ IV PhD, Associate Professor, Department of Surgery, UFMG, Belo Horizonte - MG, Brazil. \\ ${ }^{v} \mathrm{PhD}$, Associate Professor, Division of Human Anatomy, School of Health Sciences, Vale do Rio Doce University, Governador Valadares - MG, Brazil.
}

\begin{abstract}
Purpose: To evaluate the efficacy of inducing peritonitis in rats through laparoscopic cecal ligation (CL), by means of an elastic band. Methods: Twelve Wistar rats were subjected to cecal ligated with an elastic band applied using a specially constructed applicator. In six of the animals (the CL group) the cecal sac was preserved intact whilst in the remaining animals (the CLP group) the sac was perforated with scissors. Clinical parameters, characteristics of the peritoneal cavity and cecum, and histological features of the cecal tissue were observed in all experimental animals 8 and $24 \mathrm{~h}$ after surgery. Results: CLP animals exhibited at least one clinical sign of sepsis within the first $8 \mathrm{~h}$ of observation. The peritoneal liquid was observed to be clear in almost all members of the CLP. Polymorphonucleated cells were detected in the tunica serosa of the cecum of CLP animals. In contrast, all members of the CL group were alive after 24h, and of polymorphonucleated cells in the muscle layer of the cecal wall were observed. The presence of peritoneal liquid was not detected in CL animals. Conclusion: Although elastic ligation of the cecum was reproducible, puncture of the cecal sac was essential for induction of sepsis.
\end{abstract}

Key words: Models, Animal. Peritonitis. Laparoscopy. Rats.

\section{RESUMO}

Objetivo: Avaliar a eficácia de induzir peritonite em ratos através da ligadura cecal laparoscópica (CL), por meio de banda elástica. Métodos: Doze ratos Wistar foram submetidos a ligadura cecal com banda elástica aplicada com dispositivo especialmente construído para este fim. Em seis animais (grupo CL), a bolsa cecal foi mantida intacta, enquanto nos outros animais (grupo CLP), a bolsa foi perfurada com tesoura. Parâmetros clínicos, características da cavidade peritonial e ceco, e histologia do tecido cecal foram examinados em todos os animais 8 e 24 horas após a cirurgia. Resultados: Os animais do grupo CLP apresentaram pelo menos um sinal clínico de sepses nas primeiras $8 \mathrm{~h}$ de observação. Líquido peritonial claro foi observado em quase todos os membros do grupo CLP. Leucócitos polimorfonucleares foram identificados na serosa do ceco dos animais do grupo CLP. Por outro lado, todos os animais do grupo CL estavam vivos após 24 h, e leucócitos polimorfonucleares estavam restritos à muscular própria. Presença de líquido peritonial não foi detectada nos animais do grupo CL. Conclusão: A ligadura elástica do ceco foi reprodutível e a secção da bolsa cecal foi essencial para a indução de sepse.

Descritores: Modelos Animais. Peritonite. Laparoscopia. Ratos.

${ }^{1}$ Research performed at Vale do Rio Doce University, Governador Valadares - MG, Brazil.

\section{Introduction}

A number of experimental models have been applied in the study of the physiopathology of peritonitis and abdominal sepsis. One of the earliest reports on experimental peritonitis was published by Ryan and co-workers ${ }^{1}$ who induced peritonitis in rats through the technique of cecal ligation (CL), without perforation of the cecal sac, in order to study glucose metabolism. In 1980, Wichterman et $a .^{2}$ proposed a technique involving cecal ligation and puncture (CLP) as a model for inducing intra-abdominal sepsis in experimental animals. Based on clinical evolution, arterial blood pressure and laparotomic aspects, these researchers considered such a model to be adequate for the evaluation of tissue metabolism, energy production and endocrine-metabolic responses. Many years later, Hanly and co-workers ${ }^{3}$ reproduced Wichterman's model using a laparoscopic procedure. 
Although the results derived from such experimental models have often been encouraging, they have not always been reproducible in medical practice and have not generated more efficient forms of treatment. Amongst the factors that may explain such incongruity, the use of inappropriate models and the misinterpretation of the results of pre-clinical tests appear to be important $t^{4,5,6,7}$. Thus, results deriving from some studies involving humans have indicated that laparoscopic surgery may be appropriate in the treatment of peritonitis, particularly within $12 \mathrm{~h}$ of the development of the condition ${ }^{8}$. On the other hand, Ortega and Tang $^{9}$ state that technical difficulties may arise during laparoscopic procedures performed in the presence of infection which, depending on the intensity of the inflammatory process, can increase the risk of abdominal sepsis and lead to specific complications as explained by Serour ${ }^{10}$ and Soler-Dorda $G^{11}$. These authors prefer to be cautious concerning the application of laparoscopy in such situations and suggest that further research is required to reveal the severity of the problem ${ }^{9,10,11}$.

In order to expand our knowledge concerning induced peritonitis, and to improve our understanding of the physiopathology of abdominal sepsis, we have evaluated the efficacy of performing CL and CLP using a laparoscopic technique employing an elastic band rather than conventional silk thread to create the cecal sac.

\section{Methods}

The protocols employed in this project were approved by the Ethical Committee of the Vale do Rio Doce University (process 020/2004).

Twelve female albino rats (Rattus norvegicus, Wistar strain), 12 weeks old and weighing $180-250 \mathrm{~g}$, were employed in the experiments. Prior to the start of the study, animals were maintained in cages under standard conditions and provided rodent chow and water ad libitum. Experiments were carried out in four stages as follows: induction of peritonitis, clinical observations, necropsy of the dead animals or laparotomy of the surviving animals, and histological examination of the cecum.

\section{Induction of peritonitis}

For the induction of peritonitis, rats were randomly divided in two equal groups, both of which were subjected to CL by laparoscopy. In the CL group, however, the cecal sac was allowed to remain intact, whilst in the CLP group the cecal sac was ruptured.

Rats were anaesthetised with an intramuscular injection of ketamine $(100 \mathrm{mg} / \mathrm{kg})$ and immobilized with adhesive tape onto a cork board. A $2 \mathrm{~mm}$ midline incision was performed at the mesogastric region, through which a $2 \mathrm{~mm}$ trocart was introduced. A rigid endoscope $\left(1.9 \mathrm{~mm}\right.$ diameter and $12 \mathrm{~cm}$ length ; $5^{\circ}$ Panoview Plus; Richard Wolf GmbH, Knittlingen, Germany) was used in the surgical procedure. An additional $7 \mathrm{~mm}$ incision was made in the right iliac fossa, over which a laboratory-fabricated ligation device consisting of a $7 \mathrm{~mm}$ cannula (Figure 1) was positioned. Pneumoperitoneum was achieved by direct abdominal puncture using a needle $(25 \times 7 \mathrm{~mm})$, the trocart was introduced and filtered air was insufflated into the abdomen using a manual insufflator (hand aneroid from a 5086-01 sphygmomanometer; Tycos Instruments, Ardern, NC, USA). Exploration of the peritoneal cavity was performed by laparoscopy. Following identification, the cecum was pulled $10 \mathrm{~mm}$ inside the cannula of the ligation device with the help of forceps, and the cecum was ligated with an elastic band forming a constriction similar to a diverticulum (cecal sac). Using a pair of scissors introduced through the cannula of the ligation device, the cecal sacs of animals included in the CLP group were perforated by sectioning $30 \%$ of their circumference in order to release the contents into the peritoneum and to induce sepsis. In contrast, the integrity of the cecal sac was preserved in the animals of the CL group. After the surgical procedure, pneumoperitoneum was terminated, the trocart and the ligation device were removed, all incisions were closed with a 4-0 nylon thread, and the animals were returned to their cages.

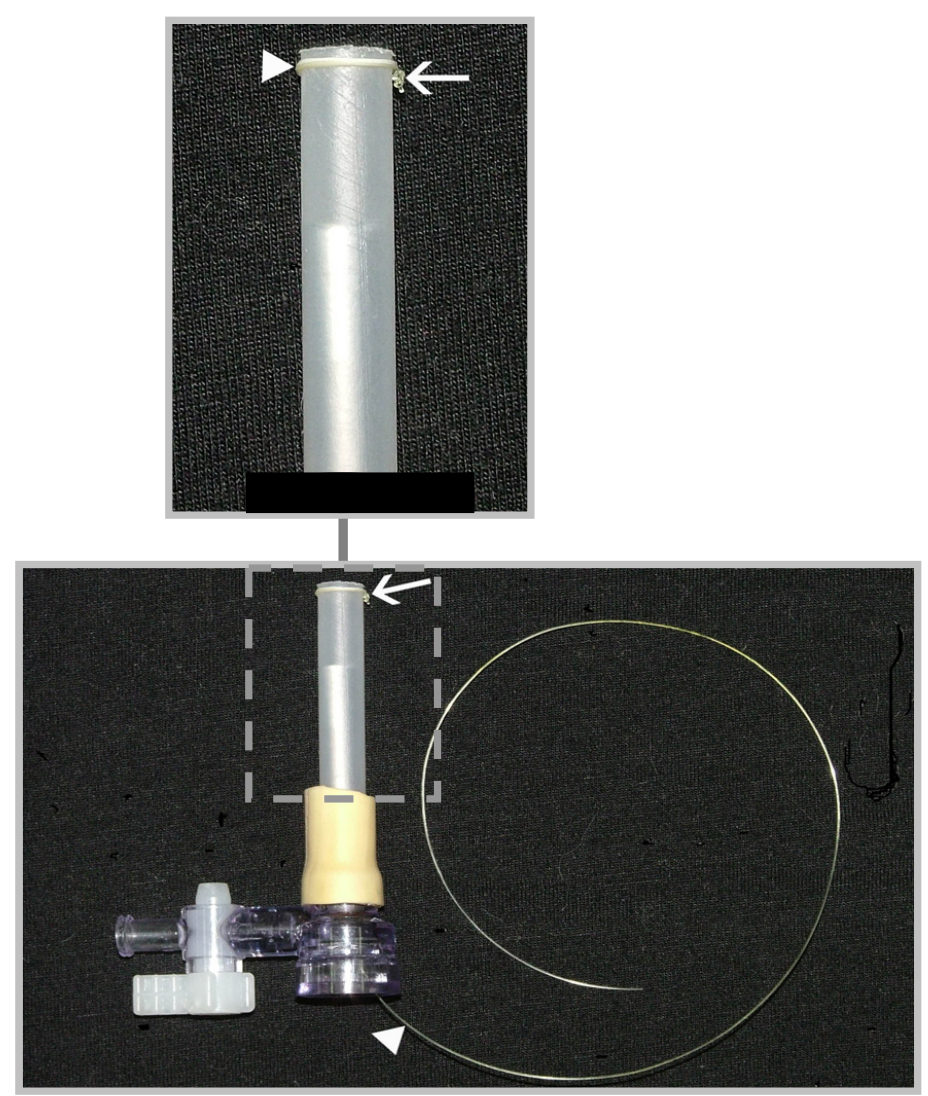

FIGURE 1 - The ligation device. The nylon thread (lower arrow) is connected to the elastic band positioned at the free end of the cannula (top arrow) by a knot (middle arrow)

\section{Clinical observations}

The animals were examined 8 and $24 \mathrm{~h}$ after surgery for clinical symptoms indicative of peritonitis including decreased activity (reduced movement, reduced grooming, progressive lethargy and decreased interest in the surroundings), piloerection, and tachypnea. Based on the data gathered, the animals were classified according to the various stages of sepsis as proposed by Wichterman et al. ${ }^{2}$ (Chart 1). 
CHART 1 - Progressive stages of sepsis in rodents based on clinical signs (adapted from Wichterman et al. ${ }^{2}$ )

Stages of peritonitis

1. Malaise and general weakness

2. Isolation

3. Poor grooming

4. Progressive lethargy and lack of interest with the surroundings

5. Piloerection

6. Reduced drinking of water

7. Tachypnea

8. Vitrified eyes with exudates

9. Concentrated and purulent urine; diarrhoea

10. No objection to the position of dorsal decubit on the table

11. Reduced level of consciousness, lack of pain sensitivity and death within $15-30 \mathrm{~min}$.

TABLE 1 - Clinical signs and histological aspects of rats submitted to experimental sepsis

\begin{tabular}{|c|c|c|c|}
\hline \multirow[b]{2}{*}{ Observations } & \multicolumn{2}{|c|}{ Animal groups } & \multirow[b]{2}{*}{$\rho$} \\
\hline & $\begin{array}{c}\text { CLP group } \\
(n=6)\end{array}$ & $\begin{array}{l}\text { CL group } \\
(n=6)\end{array}$ & \\
\hline \multicolumn{4}{|l|}{ Clinical signs* } \\
\hline Decreased activity & 5 & 0 & 0.02 \\
\hline Poor grooming & 6 & 6 & $>0.05$ \\
\hline Piloerection & 6 & 1 & 0.02 \\
\hline Tachypnea & 6 & 0 & 0.004 \\
\hline \multicolumn{4}{|l|}{ Histological aspects** } \\
\hline $\begin{array}{l}\text { Infiltration of polymorphonucleated } \\
\text { cells in the muscle layer }\end{array}$ & 6 & 6 & $>0.05$ \\
\hline $\begin{array}{l}\text { Infiltration of polymorphonucleated } \\
\text { cells in the tunica serosa }\end{array}$ & 5 & 0 & 0.02 \\
\hline $\begin{array}{l}\text { Presence of food material in the } \\
\text { extraluminal area }\end{array}$ & 5 & 0 & 0.02 \\
\hline
\end{tabular}

$\mathrm{CLP}=$ cecal ligation and puncture; $\mathrm{CL}=$ cecal ligation

* Observed $8 \mathrm{~h}$ after induction of sepsis

** Observed $24 \mathrm{~h}$ after induction of sepsis by means of light microscopy (400 x magnification) of cecal sections stained with haematoxylin eosin.

\section{Necropsy / laparotomy}

At the end of the $24 \mathrm{~h}$ observation period, animals that had died were submitted to necropsy, whilst the surviving animals were submitted to laparotomy under anaesthesia. The presence, aspect and distribution of the peritoneal liquid were evaluated, and a macroscopic examination of the cecum was conducted in order to detect the presence of necrosis and fibrin. Resection of the cecum was performed and surviving animals were submitted to euthanasia by section of the abdominal aorta.

\section{Histological examination}

The cecum was fixed in $10 \%$ buffered formalin and cecal sections were stained with haematoxylin eosin and examined using a light microscope (Alphaphot-2; Nikon, Tokyo, Japan) at $400 \mathrm{x}$ magnification in order to characterize inflammatory infiltration and to detect the presence of food material in the extraluminal tissue.

\section{Statistical analyses}

Experimental data obtained from the two experimental groups were compared using $\chi^{2}$ tests. Differences between the groups were considered significant at $p \leq 0.05$.

\section{Results}

The six animals included in the CLP group exhibited clinical signs of peritonitis such as tachypnea and piloerection, all had evolved to stage 4 of infection within $8 \mathrm{~h}$ of surgical induction, and five (83\%) died within the $24 \mathrm{~h}$ observation period (Table 1). In contrast, the six animals included in the CL group presented diverse and non-specific clinical signs of peritonitis, but no signs of infection were observed and all animals were alive $24 \mathrm{~h}$ after surgery. When stimuli were applied to the surviving animals, the responses were normal although the fur was raised, tachypnea was noticeable, and the animals were thirsty. 
Macroscopic examination of the peritoneal cavity revealed that the sizes of the cecal sacs were quite uniform (diameters between 0.5 and $1.0 \mathrm{~cm}$ ) in both groups, although there were differences in colour between the cecal sacs and the remaining portions of the ceca. One of the animals of the CL group exhibited a reaction similar to that produced by the presence of a foreign body, i.e. a crust had formed around the elastic band. Additionally, in a CLP animal that had died within $24 \mathrm{~h}$ of observation, the elastic band was found causing an obstruction in the small intestine. The presence of peritoneal liquid was not detected in CL animals, whilst the peritoneal liquid was observed to be clear in all animals of the CLP group except for that of the surviving animal, which presented a purulent secretion in and around the cecal sac.

Histological examination of the cecum of CL animals revealed that polymorphonucleated cells were restricted to the muscle layer (Figure 2), whilst in the CLP animals, infiltration of polymorphonucleated cells had reached the tunica serosa, and residues of food material could be observed in the extraluminal tissue (Figure 3).

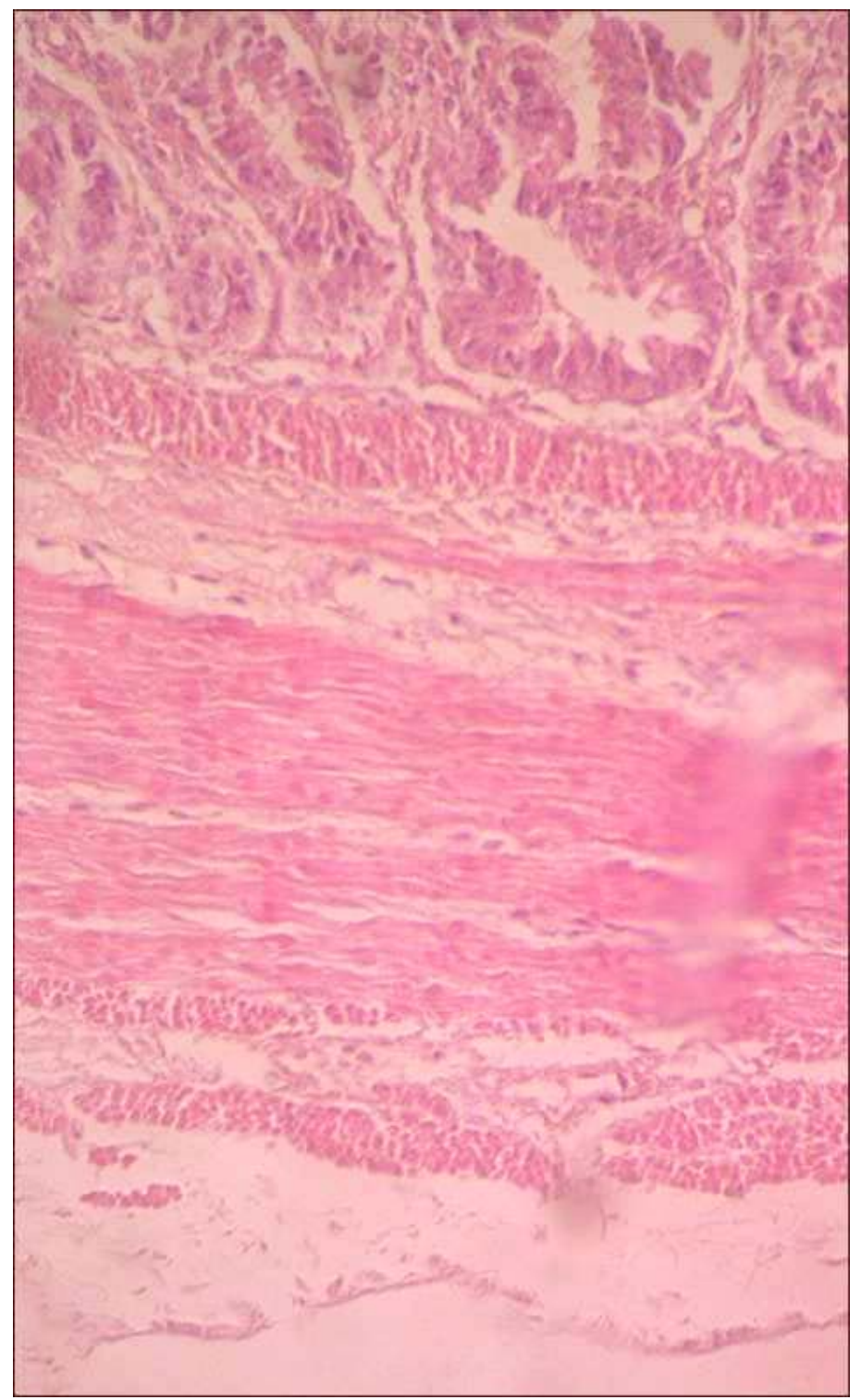

FIGURE 2 - Histological section of cecum obtained from rats submitted to cecal ligation (the CL group). Polymorphonucleated cells are restricted to the muscle layer and no food material can be observed in the extraluminal tissue

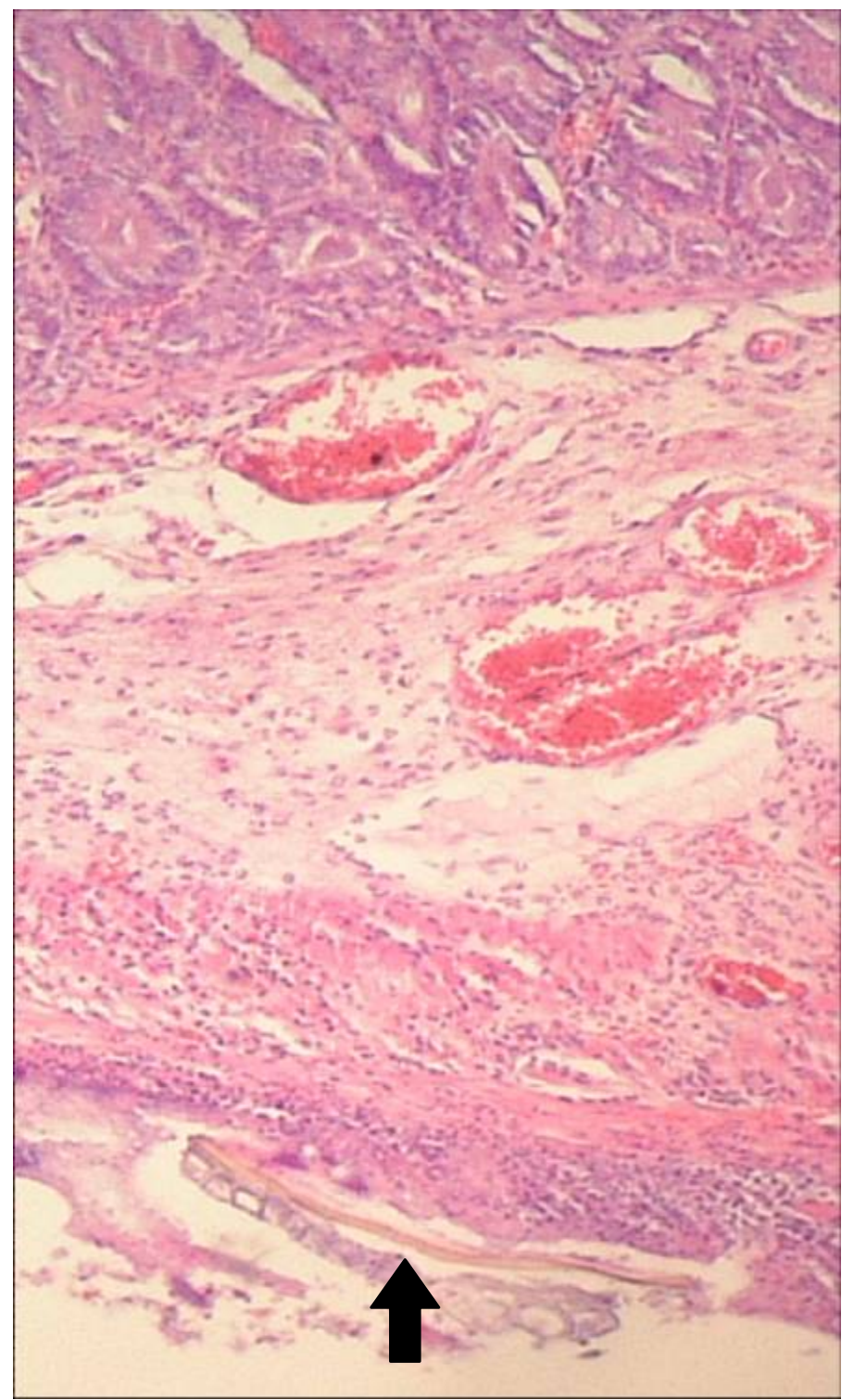

FIGURE 3 - Histological section of cecum obtained from rats submitted to cecal ligation and perforation (the CLP group). Infiltration of polymorphonucleated cells and residues of food material (arrowed) can be observed in the serous layer and in the extraluminal tissue, respectively 


\section{Discussion}

The experiments performed by Wichterman et $a .^{2}$ represented a milestone in the use of experimental models for studying the physiopathology of infection. These authors not only emphasized the importance of rupturing the integrity of the intestinal wall in the induction of peritonitis, but also demonstrated the presence of bacteria in the peripheral blood of the animals and the initiation of sepsis within $10 \mathrm{~h}$ of the surgical procedure. Additionally, the evolution of the infection, leading to eventual death, could be followed through the manifestation of specific clinical signs that were used to classify eleven stages of sepsis.

According to Mathiak and co-workers ${ }^{12}$, the major problem associated with Wichterman's model for the induction of peritonitis is that cecal ligation is very difficult to reproduce within a large number of animals using conventional methods. An alternative technique has been described by Salgado Junior et $a l .{ }^{13}$ in which a $3 \mathrm{~mm}$ plastic mould was employed, but ligation still involved the use of silk thread.

The ligation technique using an elastic band as described in the present study was facile and rapid, and produced uniform results. Since reproducibility is of paramount importance in obtaining replicate results for the purposes of comparing peritoneal damage within different experimental groups, we conducted a preliminary investigation ${ }^{14}$ in which three elastic band ligation devices of different diameters were tested for the ligation of chicken intestines. The results showed that the device with a cannula diameter of $7 \mathrm{~mm}$ was able to produce cecal sacs of a suitable size to allow perforation and release of faecal material into the abdomen. When the elastic band ligation method was applied to rats, the size of the cecal sac formed was uniformly reproduced in all of the experimental animals, thus generating minimal interference with the subsequent acquisition of results.

CLP is the most commonly employed animal model for the induction of experimental peritonitis since it presents a marked similarity with the physiopathology of secondary peritonitis observed in humans, in which peritoneal irritation, necrosis, persistent discharge of faecal material within the abdomen and increase in the concentration of cytokines are observed. In the present study, one group of experimental animals was submitted to CLP whilst a second group was subjected only to CL. Each group was formed of six rats since this represented the minimum population size required to generate statistically valid results. The parameters analysed following the surgical procedure included the clinical aspects of sepsis, together with the macro- and microscopical aspects of the abdominal fluid and intestinal tissue. We opted to commence the observation of the experimental animals $8 \mathrm{~h}$ after the induction of peritonitis in order to classify them according to the parameters proposed by Wichterman et al. ${ }^{2}$.

As expected, the outcomes for the two groups of experimental animals were convincingly dissimilar, thus justifying the small number of rats employed in the study. The average survival time of the animals within the CLP group was comparable with that recently published ${ }^{15}$ for rats submitted to CLP and maintained under normothermia and anaesthesia, i.e. $289 \pm 17 \mathrm{~min}$. However, the mortality rate of the animals within the CLP group $(83 \%)$ differed considerably from values of $15 \%{ }^{16}$ and $13 \%{ }^{2}$ previously reported for animals submitted to cecal sac puncture.
In the former study, however, the animals received volemic resuscitation in the presence and absence of antibiotics ${ }^{16}$, although in the latter study no treatment was applied to the animals ${ }^{2}$.

The discrepancy between the present results and those previously reported may be explained by the technique employed in the puncture of the cecal sac, which produced ischemia associated with the release of faecal content into the abdominal cavity. Some researchers have concluded that the intensity of sepsis could be modulated by the calibre of the needle used in the perforation of the cecal wall. Using needles of different calibre, Ebong and co-workers ${ }^{17}$ demonstrated that it was possible to predict the intensity of the local inflammatory and systemic response by standardizing the size of the needle. In the present study we have used a pair of scissors because in laparoscopy it is technically difficult to produce a puncture in an exact location using needles. By using a pair of scissors the puncture was performed without having to create an additional entry port.

In the present study, laparoscopy was employed to induce sepsis in the CL and CLP groups, and the results were in agreement with those previously reported by other authors who used either laparoscopic ${ }^{3}$ or laparotomic ${ }^{2}$ techniques. Moreover, the experimental model described in the present paper is more consistent than that employed by Ryan and co-workers ${ }^{1}$, who investigated only one technique (CL) and employed a larger number of animals. Despite these advantages, however, the precise determination of the local and systemic damage produced by sepsis still remains a challenge.

\section{Conclusion}

The experimental model proposed in this paper, in which laparoscopy and elastic ligation of the cecum were used for inducing peritonitis, produced reliable results. Moreover, puncturing the cecal sac was absolutely essential in generating clinical and histological signs of sepsis, since elastic ligation alone was unable to produce such manifestations.

\section{References}

1. Ryan NT, Blackburn GL, Clowes HA. Differential tissue sensitivity to elevated endogenous insulin levels during experimental peritonitis in rats. Metabolism. 1974;23:1081-9.

2. Wichterman KA, Baue AE, Chaudry IH. Sepsis and septic shock: a review of laboratory models and a proposal. J Surg Res. 1980;29:189-201. 3. Hanly EJ, Mendonza-Sagaon M, Murata K, Hadacre JM, De Maio A, Talamini MA. CO2 pneumoperitoneum modifies the inflammatory response to sepsis. Ann Surg. 2003;237:343-50.

4. Garrido AG, Figueiredo LFP, Silva MR. Experimental models of sepsis and septic shock: an overview. Acta Cir Bras. 2004;19:82-8.

5. Gupta A, Watson DI. Effect of laparoscopy on immune function. Br J Surg. 2001;88:1296-306.

6. Parker SJ, Watkins PE. Experimental models of gram-negative sepsis. Br J Surg. 2001;88:22-30.

7. Marshall JC, Deitch E, Moldawer LL, Opal S, Redl H, van der Poll T. Preclinical models of shock and sepsis: what can they tell us? Shock. 2005; 24(Suppl. 1):1-6.

8. Pokala N, Sadhasivam S; Kiran RP; Parithivel V. Complicated appendicitis: is the laparoscopic approach appropriate? A comparative study with the open approach: outcome in a community hospital setting. Am Surg. 2007;73:737-41. 
9. Ortega AE, Tang E. Laparoscopic appendectomy. In: Toouli J, Gossot D, Hunter JG. Endosurgery. New York: Churchill Livingstone; 1996. p.657-64. 10. Serour F, Witzling M, Gorenstein A. Is laparoscopic appendectomy in children associated with an uncommon postoperative complication? Surg Endosc. 2005;19:919-22.

11. Soler-Dorda G, Fernández-Díaz MJ, Martín-Parra I, Alonso-Gayón JL, Conty-Serrano JL, de Andrés-Fuertes MA, Bárcena-Barros JM. Complicaciones sépticas intraabdominales tras apendicectomía laparoscópica: descripción de una posible nueva complicación específica de la apendicectomía laparoscópica. Cir Esp. 2007;82:21-6.

12. Mathiak G, Szewczyk D, Abdullah F, Ovadia P, Feuerstein G, Rabinovici $\mathrm{R}$. An improved clinically relevant sepsis model in the conscious rat. Crit Care Med. 2000;28:1947-52.

13. Salgado Junior W, Cunha FQ, Sankarankuty AS, Santos JS. Desenvolvimento de modelo de peritonite bacteriana para avaliação do tratamento mediante acesso laparotômico e video-laparoscópico. Acta Cir Bras. 2001;16(Suppl. 1):9-12.
14. Bicalho PRR, Moreno TP, Alvarenga DG, Reis FA, Duval-Araujo I. Ligadura elástica de intestino de frango: modelo para simulação de peritonite bacteriana. In: II Simpósio de Pesquisa e Iniciação Científica da UNIVALE; 2004. Governador Valadares, MG: Editora Univale; 2004. p.104.

15. L'Her E, Amerand A, Vettier A, Sebert P. Effects of mild induced hypothermia during experimental sepsis. Crit Care Med. 2006;34:2621-3.

16. Ritter C, Andrades M, Frota Júnior ML, Bonatto F, Pinho RA, Polydoro M, Klamt F, Pinheiro CT, Menna-Barreto SS, Moreira JC, Dal-Pizzol F. Oxidative parameters and mortality in sepsis induced by cecal ligation and perforation. Intensive Care Med. 2003;29:1782-9.

17. Ebong S, Call D, Nemzek J, Bolgos G, Newcomb D, Remick D. Immunopathologic alterations in murine models of sepsis of increasing severity. Infect Immunol. 1999;67:6603-10.

Conflict of interest: none Financial source: scientific initiation grants Vale do Rio Doce University

\section{Correspondence:}

Paulo R. R. Bicallho

Escola de Ciências da Saúde

Universidade do Vale do Rio Doce

35010-230 Governador Valadares - MG Brazil

Phone/Fax: (55 33)3277-8272

gpbicalho1@uol.com.br

Received: March 18, 2008

Review: May 20, 2008

Accepted: June 24, 2008

\section{How to cite this article}

Bicalho PRR, Lima LB, Alvarenga DG, Duval-Araújo I, Nunes TA, Reis FA. Clinical and histological responses to laparoscopically-induced peritonitis in rats. Acta Cir Bras. [serial on the Internet] 2008 Sept-Oct;23(5). Available from URL: http://www.scielo.br/acb

*Color figures available from www.scielo.br/acb 